\title{
Effect of $\alpha$-tocopherol supplementation on growth performance, antioxidant activity and nutrient digestibility of Labeo rohita (Hamilton 1822) fingerlings fed corn gluten meal-based diet
}

\author{
MUHAMMAD ARSHAD ${ }^{1}$, SYED MAKHDOOM HUSSAIN ${ }^{1}$, AZHAR RAFIQUE ${ }^{1}$, FAROOQ \\ AHMAD $^{2}$, MUHAMMAD MUDASSAR SHAHZAD ${ }^{3}$, ILKNUR UCAK ${ }^{4}$, ARSHAD JAVID ${ }^{5}$, \\ HAMDA AZMAT $^{6}$, ABDULLAH IJAZ HUSSAIN ${ }^{7}$, AQSA SHARIF $^{1}$ AND MUHAMMAD ASRAR ${ }^{1}$ \\ ${ }^{1}$ Fish Nutrition Lab, Department of Zoology, Government College University, Faisalabad, Pakistan \\ ${ }^{2}$ Department of Zoology, The Islamia University of Bahawalpur, Pakistan \\ ${ }^{3}$ Department of Zoology, Division of Science and Technology, University of Education, Lahore, Pakistan \\ ${ }^{4}$ Department of Animal Production and Technologies, Faculty of Agricultural Sciences and Technologies, Nigde Omer \\ Halisdemir University, 51240, Nigde/Turkey \\ ${ }^{5}$ Department of Wildlife and Ecology, University of Veterinary and Animal Sciences, Lahore, Pakistan \\ ${ }^{6}$ Department of Fisheries and Aquaculture, University of Veterinary and Animal Sciences, Lahore, Pakistan \\ ${ }^{7}$ Department of Chemistry, Government College University, Faisalabad, Pakistan \\ e-mail:drmakhdoom90@gmail.com
}

\begin{abstract}
A 70 days feeding trial was conducted to determine the effects of $\boldsymbol{\alpha}$-tocopherol (vitamin E) on the growth performance, antioxidant activity and nutrient digestibility of Labeo rohita (Hamilton 1822) fingerlings fed corn gluten meal based diet. Fingerlings (initial average weight: $6.35 \mathrm{~g}$ ) were fed seven graded levels of $\boldsymbol{\alpha}$-tocopherol viz., 0, 100, 200, 300, 400, 500 and $600 \mathrm{mg} \mathrm{kg}^{-1}$. Triplicate tanks were used and each tank housed 15 fingerlings. Fish were fed at the rate of $5 \%$ of live wet weight. Collected data was subjected to one-way analysis of variance (ANOVA). Results showed that fingerlings fed with $200 \mathrm{mg} \mathrm{kg}^{-1}$ of $\boldsymbol{\alpha}$-tocopherol showed significantly $(\mathrm{p}<0.05)$ higher weight gain $(32.73 \mathrm{~g})$, weight gain $\%(261 \%)$ and suitable feed conversion ratio (2.49). Among other experimental and control diets, optimum apparent digestibility coefficient (ADC\%) of crude protein (CP) (73\%), ether extract (EE) (74\%) and gross energy (GE) $(63 \%)$ was noted in the fish fed $200 \mathrm{mg} \mathrm{kg}^{-1}$ diet. Minimum oxidation (\%) (7.66\%) was observed at $600 \mathrm{mg} \mathrm{kg}^{-1}$ predicting that the antioxidant activity increased in a dose-dependent manner.
\end{abstract}

Keywords: $\alpha$-tocopherol, Antioxidant activity, Aquaculture, Corn gluten meal, Growth

\section{Introduction}

Animal protein is an essential part of human food and fish has high protein and low amount of fats which is valuable for human health. Conventional source of protein for fish farming is fish meal (FM), as it has well balanced amino acid and fatty acid profile, has excellent protein content, appetising taste and absorb well in the fish gut (Wang et al., 2019). But presently, the FM supply is facing decline and since long its production supports only negligible yield (Bai et al., 2019). To combat this imbalance between fish meal production and its demand, scientists are exploring alternative plant protein sources for fish (Teves and Ragaza, 2016). It has become a matter of interest globally for aquaculturists and fish nutritionists over more than two decades (Bai et al., 2019).

Corn gluten meal (CGM) is produced as a side-product of corn wet grinding procedure used for the dissociation of protein, starch, gums and fiber components (Wang et al., 2016). It is advantageous as compared to other plant meals because of steady and local supply, high protein content within range of $60-70 \%$ (dry matter), less amount of anti-nutritional factors, small content of fibres and particularly cost-effective (Glencross, 2016). Because of its high protein value, CGM is commonly used in place of other plants or animal-based proteins such as fish meal and soybean meal (Cha et al., 2000). Various studies confirm the successful replacement of FM with CGM at different inclusion levels illustrating more than $50 \%$ substitution without decrease in growth performance in carnivorous fishes like seabream, cobia and Japanese seabass (Yigit et al., 2012; Luo et al., 2013 and Men et al., 2014). Molina-Poveda et al. (2015) described that 100\% replacement of FM with CGM resulted in reduced (30\%) growth rate of white shrimp, while only $20-40 \%$ inclusion level provided good results. 
Labeo rohita is a cyprinid, also called "rohu" or "rui", is the most economical fish among other Indian major carps (IMCs) with its rapid growth rate, nutritional value and high consumer demand (Mohapatra et al., 2012). It is a column feeder and omnivorous in nature and can easily be raised in fish polyculture systems (Goswami et al., 2020). It is a highly preferred fish species and according to FAO (2012), over $35 \%$ of the total carp production was contributed by this species since previous decade. Vitamin E belongs to the group of fat-soluble molecules; exists in the form of four tocopherols and four tocotrienols; of which highest vitamin E biopotency is present in $\alpha$-tocopherol (NRC, 2011). It is a valuable antioxidant, benefits the animal by saving cellular membranes, lipids and lipoproteins from free radical based damage (Bender, 2003).

Generally, vitamin E maintains immunity (Salinthone et al., 2013; Zhou et al., 2013), saves cell membrane from peroxide damage (Li et al., 2014), ameliorates resistance to high stocking density induced stress (Liu et al., 2014) and improves tissue composition in fish like black seabream (Peng et al., 2009), turbot and gilthead seabream (Tocher et al., 2002). Supplemented form of vitamin $E$ in fish diet is $\alpha$-tocopherol acetate, as it confers higher stability and oxidation resistance even during feed processing events (Peng et al., 2009). $\alpha$-tocopherol shows positive effects on antioxidant activity and lipid peroxidation of grass carp and turbot respectively (Li et al., 2014; Jia et al., 2017). A number of studies reported that $\alpha$-tocopherol is required for fish and terrestrial animals because its function is to improve growth performance, nutrient digestibility, reproductive performance and disease resistance (Lee et al., 2003). However, over dosage of $\alpha$-tocopherol in certain fish species may show various abnormal behaviours (Zhang et al., 2016). For instance, Wang et al. (2015) found that $300 \mathrm{mg} \mathrm{kg}^{-1}$ inclusion level of $\alpha$-tocopherol in fish diet worked as a pro-oxidant; in spite of antioxidant. So, proper dietary requirement of the fish should be well known before its supplementation in the diet. Therefore, the main objective of this study was to evaluate the potential of $\alpha$-tocopherol on growth performance, anti-oxidant activity and nutrient digestibility of $L$. rohita fingerlings fed corn gluten meal based diets.

\section{Materials and methods}

The experiment was carried out in the Fish Nutrition Laboratory, Department of Zoology, Government College University, Faisalabad, Pakistan.

\section{Fish acclimatisation and culture conditions}

L. rohita fingerlings were brought from Govt. Fish Seed Hatchery, Satiana Road, Faisalabad. Fingerlings were stocked in V-shaped tanks having 701 capacity (especially made for faeces collection) and acclimated to laboratory conditions for 15 days (Rowland and Ingram, 1991). Fish were fed basal diet once a day to apparent satiation (Allan and Rowland, 1992). Prior to the start of the experiment, $L$. rohita fingerlings were bathed in saline solution $\left(\mathrm{NaCl} 5 \mathrm{~g} \mathrm{l}^{-1}\right)$ so as to free the fish from fungal infection and ectoparasites. On a daily basis, dissolved oxygen, temperature and $\mathrm{pH}$ were checked by $\mathrm{DO}$ meter (Jenway 970), thermometer and pH meter (Jenway 3510) respectively. Aeration ( $24 \mathrm{~h}$ ) was provided by capillary system to all the experimental tanks.

\section{Feed ingredients and experimental diets}

All the feed constituents were ground to pass through $0.5 \mathrm{~mm}$ sieve and the ground ingredients were mixed in an electric mixer for $5 \mathrm{~min}$, while fish oil was added slowly. To make an appropriate dough, 10-15\% water was added (Lovell, 1989). Ingredients composition of the test diets is given in Table 1. The dough was processed in a pelleting machine to make feed pellets. Corn gluten meal-based diet was supplemented with different levels of $\alpha$-tocopherol at $100,200,300,400,500$ and $600 \mathrm{mg} \mathrm{kg}^{-1}$.

\section{Feeding protocol}

Rohu fingerlings were fed at $5 \%$ of their body weight, two times a day, for a period of 70 days. Tanks in triplicate were set for each experimental diet and 15 fingerlings were kept in each tank. After the feeding period of $2 \mathrm{~h}$, the unconsumed diet was drained out from each tank by opening the valves of the tanks. Faeces were collected through faecal collecting tube of each tank. To minimise leakage of nutrients, care was taken to evade the breaking of thin faecal strings. The material from each treatment was dried in oven, ground and stored for chemical analysis.

Growth study

At the start and end of the experiment, fish in each tank was bulk weighed to determine the growth performance of fingerlings following standard formulae:

$$
\begin{aligned}
& \text { Weight gain } \%=\frac{(\text { Final weight }- \text { Initial weight })}{\text { (Initial weight) }} \times 100 \\
& \text { FCR }=\frac{\text { Total dry feed intake }(\mathrm{g})}{\text { Wet weight gain }(\mathrm{g})} \\
& \text { SGR } \%=\frac{\text { Final weight }(\mathrm{g}) \text { - Initial weight }(\mathrm{g})}{\text { No. of experiment days }} \times 100
\end{aligned}
$$

\section{Chemical analysis of feed and feces}

With the use of mortar and pestle, feed ingredients, experimental diets and collected faecal samples were 
Table 1. Ingredient composition (\%) of test diets

\begin{tabular}{|c|c|c|c|c|c|c|c|}
\hline Ingredients & Test Diet-I (Control) & Test Diet-II & Test Diet-III & Test Diet-IV & Test Diet-V & Test Diet-VI & Test Diet-VII \\
\hline$\overline{\alpha \text {-tocopherol }\left(\mathrm{mg} \mathrm{kg}^{-1}\right)}$ & 0 & 100 & 200 & 300 & 400 & 500 & 600 \\
\hline Corn gluten meal & 55 & 55 & 55 & 55 & 55 & 55 & 55 \\
\hline Fish meal & 16 & 16 & 16 & 16 & 16 & 16 & 16 \\
\hline Wheat flour* & 11 & 11 & 11 & 11 & 11 & 11 & 11 \\
\hline Soybean meal & 8 & 8 & 8 & 8 & 8 & 8 & 8 \\
\hline Fish oil & 6 & 6 & 6 & 6 & 6 & 6 & 6 \\
\hline Vitamin premix & 1 & 1 & 1 & 1 & 1 & 1 & 1 \\
\hline Mineral mixture & 1 & 1 & 1 & 1 & 1 & 1 & 1 \\
\hline Ascorbic acid & 1 & 1 & 1 & 1 & 1 & 1 & 1 \\
\hline Chromic oxide & 1 & 1 & 1 & 1 & 1 & 1 & 1 \\
\hline Total & 100 & 100 & 100 & 100 & 100 & 100 & 100 \\
\hline
\end{tabular}

* $\alpha$-tocopherol was supplemented at the cost of wheat flour

Proximate composition (\%) of feed ingredients

\begin{tabular}{lllll}
\hline Ingredients & Fish meal & Soybean meal & Wheat flour & Corn gluten meal \\
\hline Dry matter (\%) & 91.65 & 93.51 & 92.49 & 92.90 \\
Crude protein (\%) & 48.93 & 11.17 & 09.94 & 57.68 \\
Crude fat (\%) & 7.23 & 4.59 & 2.28 & 3.75 \\
Crude fibre (\%) & 0.93 & 3.82 & 2.12 & 1.39 \\
Ash (\%) & 25.15 & 10.92 & 1.97 & 2.66 \\
Gross energy (kcal g $\left.{ }^{-1}\right)$ & 2.63 & 3.18 & 3.04 & 3.93 \\
Carbohydrates & 18.67 & 46.21 & 82.88 & 34.16 \\
\hline
\end{tabular}

homogenised and analysed following standard methods (AOAC, 1995). Crude protein $(\mathrm{N} \times 6.25)$ was assessed by micro-Kjeldahl apparatus, moisture through stove drying at $105^{\circ} \mathrm{C}$ for $12 \mathrm{~h}$, crude fat by petroleum ether extraction method through Soxtec HT2 1045 system, ash by ignition at $650^{\circ} \mathrm{C}$ for $12 \mathrm{~h}$ in electric furnace (Eyela-TMF 3100) to constant weight and crude fibre as loss on ignition of dried residues that are lipid-free after digestion with 1:1 of $\mathrm{NaOH}$ and $\mathrm{H}_{2} \mathrm{SO}_{4}$. Gross energy was evaluated using oxygen bomb calorimeter.

\section{Digestibility studies}

Chromic acid was included in the diet $(1 \%)$ to determine apparent digestibility coefficient (ADC\%) of nutrients. By employing acid digestion method (Divakaran et al., 2002) in UV-VIS 2001 spectrophotometer at $350 \mathrm{~nm}$, chromic oxide content in the samples of experimental diets and faeces was oxidised with perchloric reagent. By using the following formula (NRC, 1993), apparent nutrient digestibility coefficient (\%) of experimental diets was evaluated.

ADC $(\%)=100-100 \times \frac{\text { Percent marker in diet } \times \text { Percent nutrient in faeces }}{\text { Percent marker in faeces } \times \text { Percent nutrient in diet }}$

\section{Determination of antioxidant activity}

The effect of $\alpha$-tocopherol supplemented diets on antioxidant activity, in terms of $\%$ inhibition of oxidation in L. rohita was checked following methods described by Hussain et al. (2011) with some modifications. Collected samples of fish from each group was dried, ground and transferred to different test tubes, then hexane fraction was prepared by mixing $1 \mathrm{~g}$ of ground sample with 10 $\mathrm{ml}$ of $\mathrm{n}$-hexane in each test tube. Following this, test tubes having hexane fraction were heated gently in water bath for about $10 \mathrm{~min}$. To prepare $10 \mathrm{ml}$ solution of $0.2 \mathrm{M}$, phosphate buffer was added in each test tube. After mixing gently, $200 \mu \mathrm{l}$ from each test tube was poured into new tubes and equal ratio $(200 \mu \mathrm{l})$ of $35 \%$ ferrous chloride solution and $30 \%$ aqueous ammonium thiocyanate solution was added respectively and absorbance was determined in a spectrophotometer at $500 \mathrm{~nm}$ by adding $10 \mathrm{ml}$ of $95 \%$ ethanol in each test tube. To assess the inhibition of oxidation (\%), following formulae were used:

$$
\begin{aligned}
& \% \text { inhibition }=[(\mathrm{A} 0-\mathrm{As}) / \mathrm{A} 0] \times 100 \\
& \text { Oxidation }(\%)=100-100 \times(\mathrm{A} 0-\mathrm{As} / \mathrm{A} 0)
\end{aligned}
$$

In the above equations, $\mathrm{A} 0$ and $\mathrm{As}$ are the absorbance of control and sample after 0 to $5 \mathrm{~min}$, respectively.

\section{Statistical analysis}

ANOVA was applied on the data of growth performance (Steel et al., 1996). The differences between means was compared by Tukey's Honestly Significant Difference Test and considered significant at $\mathrm{p}<0.05$ 
(Snedecor and Cochran, 1991). For statistical analysis, the Co-Stat computer software (Version 6.303, PMB 320, Monterey, CA, 93940 USA) was used.

\section{Results}

Graded levels of $\alpha$-tocopherol significantly affected growth performance of L. rohita fingerlings (Table 2). The weight gain (WG), weight gain percentage (WG\%) and suitable feed conversion ratio (FCR) values of L. rohita fingerlings fed $\alpha$-tocopherol at $200 \mathrm{mg} \mathrm{kg}^{-1}$ was significantly $(\mathrm{p}<0.05)$ different than the other experimental and control diets. Initial weight of all the fingerlings was more or less similar but final weight was significantly different from each other. Maximum weight gain and weight gain $\%$ of $23.67 \mathrm{~g}$ and $261 \%$, respectively were recorded in L. rohita fingerlings fed at $200 \mathrm{mg} \mathrm{kg}^{-1}$ of $\alpha$-tocopherol followed by the fish fed at $300 \mathrm{mg} \mathrm{kg}^{-1}$ (21.09 $\mathrm{g}$ and 232\%). Weight gain increased with an increase in the levels of vitamin $\mathrm{E}$ up to $200 \mathrm{mg} \mathrm{kg}^{-1}$, while further increase of vitamin $\mathrm{E}$ from $300-600 \mathrm{mg} \mathrm{kg}^{-1}$ decreased WG significantly $(\mathrm{p}<0.05)$. The best FCR value was detected at $300 \mathrm{mg} \mathrm{kg}^{-1}$ of $\alpha$-tocopherol (2.49) while the second optimum value was at $200 \mathrm{mg} \mathrm{kg}^{-1}$ (2.39).

Nutritional composition of all the test diets fed to L. rohita fingerlings was similar (Table 3 ). The analysed composition of nutrients like crude protein, ether extract and gross energy in the faeces is given in Table 4. It was observed from the results that $\alpha$-tocopherol supplementation in corn gluten meal based diet played a significant $(\mathrm{p}<0.05)$ role in improving apparent digestibility of $\mathrm{CP}(73 \%), \mathrm{EE}(74 \%)$ and GE (63\%) at $200 \mathrm{mg} \mathrm{kg}^{-1}$ level (Table 5), so less nutrients were excreted out from the fish body. An increasing trend was observed in nutrients digestibility up to diet III having $200 \mathrm{mg} \mathrm{kg}^{-1}$ of $\alpha$-tocopherol in diet, where it reached its maximum. However, further increase in $\alpha$-tocopherol supplementation resulted in reduced nutrient digestibility. The second higher values of nutrients absorption were met by applying $300 \mathrm{mg} \mathrm{kg}^{-1}$ of $\alpha$-tocopherol (CP $68 \%$, EE $73 \%$, GE $62 \%$ ). Alternatively, control diet (i.e., having no $\alpha$-tocopherol) resulted in highest excretion of nutrients in faeces as; CP 55\%, EE $61 \%$ and GE 52\%, which were significantly different from each test diet.

The antioxidant activity of $\alpha$-tocopherol supplemented corn gluten meal based diet at various levels is presented in Table 6. Results were obtained by using percentage of oxidation as a parameter to know the effect of $\alpha$-tocopherol in each diet. Experimental diet VII having $600 \mathrm{mg} \mathrm{kg}^{-1}$ of $\alpha$-tocopherol was found to be

Table 2. Growth performance of $L$. rohita fingerlings fed $\alpha$-tocopherol supplemented corn gluten meal based diets

\begin{tabular}{|c|c|c|c|c|c|c|c|}
\hline \multirow{3}{*}{ Growth parameters } & \multicolumn{6}{|c|}{$\alpha$-tocopherol levels $\left(\mathrm{mg} \mathrm{kg}^{-1}\right)$} & \multirow[b]{2}{*}{ Diet VII } \\
\hline & $\begin{array}{l}\text { Diet I } \\
\text { (Control diet) }\end{array}$ & Diet II & Diet III & Diet IV & Diet V & Diet VI & \\
\hline & $\overline{0}$ & 100 & 200 & 300 & 400 & 500 & 600 \\
\hline IW (g) & $9.09 \pm 0.02^{\mathrm{a}}$ & $9.08 \pm 0.13^{\mathrm{a}}$ & $9.06 \pm 0.03^{\mathrm{a}}$ & $9.08 \pm 0.02^{\mathrm{a}}$ & $9.10 \pm 0.10^{\mathrm{a}}$ & $9.06 \pm 0.03^{\mathrm{a}}$ & $9.10 \pm 0.03^{\mathrm{a}}$ \\
\hline FW $(g)$ & $23.71 \pm 0.13^{\mathrm{g}}$ & $29.11 \pm 0.05^{\mathrm{c}}$ & $32.73 \pm 0.05^{\mathrm{a}}$ & $30.17 \pm 0.06^{b}$ & $27.44 \pm 0.19^{d}$ & $27.44 \pm 0.19^{\mathrm{e}}$ & $26.85 \pm 0.05^{\mathrm{f}}$ \\
\hline WG (g) & $14.62 \pm 0.15^{\mathrm{e}}$ & $20.03 \pm 0.04^{\mathrm{de}}$ & $23.67 \pm 0.15^{\mathrm{c}}$ & $21.09 \pm 0.08^{\mathrm{bc}}$ & $19.11 \pm 0.08^{\mathrm{a}}$ & $18.39 \pm 0.16^{\mathrm{b}}$ & $17.75 \pm 0.04^{\mathrm{b}}$ \\
\hline WG $(\%)$ & $160.84 \pm 0.82^{\mathrm{a}}$ & $220.71 \pm 0.83^{c}$ & $261.32 \pm 0.68^{\mathrm{a}}$ & $232.19 \pm 0.87^{\mathrm{b}}$ & $209.97 \pm 0.78^{\mathrm{d}}$ & $203.02 \pm 1.11^{\mathrm{e}}$ & $195.16 \pm 0.29^{\mathrm{f}}$ \\
\hline WG $\left(\right.$ fish $^{-1}$ day $\left.^{-1}\right) g$ & $0.21 \pm 0.00^{\mathrm{d}}$ & $0.29 \pm 0.00^{\mathrm{d}}$ & $0.34 \pm 0.00^{\mathrm{cd}}$ & $0.30 \pm 0.00^{\mathrm{b}}$ & $0.27 \pm 0.00^{\mathrm{a}}$ & $0.26 \pm 0.00^{\mathrm{bc}}$ & $0.25 \pm 0.00^{\mathrm{d}}$ \\
\hline FI & $0.41 \pm 0.03^{\mathrm{a}}$ & $0.42 \pm 0.01^{\mathrm{d}}$ & $0.43 \pm 0.03^{\mathrm{cd}}$ & $0.42 \pm 0.01^{\mathrm{ab}}$ & $0.43 \pm 0.02^{\mathrm{e}}$ & $0.44 \pm 0.02^{\mathrm{ab}}$ & $0.45 \pm 0.02^{\mathrm{a}}$ \\
\hline FCR & $2.77 \pm 0.14^{\mathrm{a}}$ & $2.62 \pm 0.07^{\mathrm{cd}}$ & $2.49 \pm 0.10^{\mathrm{d}}$ & $2.39 \pm 0.03^{\mathrm{bc}}$ & $2.49 \pm 0.10^{\mathrm{ab}}$ & $2.52 \pm 0.10^{\mathrm{a}}$ & $2.55 \pm 0.08^{\mathrm{e}}$ \\
\hline
\end{tabular}

Means within rows having different superscripts are significantly different at $\mathrm{p}<0.05$

Data are means of three replicates

$\mathrm{IW}=$ Initial weight, $\mathrm{FW}=$ Final weight, $\mathrm{WG}=$ Weight gain, $\mathrm{FI}=$ Feed intake, $\mathrm{FCR}=$ Feed conversion ratio

Table 3. Nutrient compositions (\%) in feed of L. rohita fingerlings fed on corn gluten meal based diet with supplementation of $\alpha$-tocopherol

\begin{tabular}{lllll}
\hline Experimental diets & $\alpha$-tocopherol levels & CP & EE & GE $\left.(\mathrm{kcal} \mathrm{g})^{-1}\right)$ \\
\hline Diet I & 0 & $30.87 \pm 0.02^{\mathrm{a}}$ & $7.70 \pm 0.14^{\mathrm{bc}}$ & $4.12 \pm 0.01^{\mathrm{a}}$ \\
Diet II & 100 & $30.87 \pm 0.02^{\mathrm{a}}$ & $7.73 \pm 0.08^{\mathrm{b}}$ & $4.26 \pm 0.04^{\mathrm{a}}$ \\
Diet III & 200 & $30.89 \pm 0.02^{\mathrm{a}}$ & $7.81 \pm 0.06^{\mathrm{a}}$ & $4.30 \pm 0.03^{\mathrm{a}}$ \\
Diet IV & 300 & $30.88 \pm 0.03^{\mathrm{a}}$ & $7.90 \pm 0.06^{\mathrm{b}}$ & $4.23 \pm 0.02^{\mathrm{a}}$ \\
Diet V & 400 & $30.86 \pm 0.02^{\mathrm{a}}$ & $7.82 \pm 0.06^{\mathrm{bc}}$ & $4.26 \pm 0.03^{\mathrm{a}}$ \\
Diet VI & 500 & $30.88 \pm 0.02^{\mathrm{a}}$ & $7.81 \pm 0.07^{\mathrm{bc}}$ & $4.23 \pm 0.02 \mathrm{a}$ \\
Diet VII & 600 & $30.87 \pm 0.02^{\mathrm{a}}$ & $7.80 \pm 0.06^{\mathrm{c}}$ & $4.26 \pm 0.03^{\mathrm{ab}}$ \\
\hline
\end{tabular}

Means within rows having different superscripts are significantly different at $\mathrm{p}<0.05$

Data are means of three replicates 
Table 4. CP, EE and GE $\left(\mathrm{kcal} \mathrm{g}^{-1}\right)$ in faeces of $L$. rohita fingerlings fed on $\alpha$-tocopherol supplemented corn gluten meal based diet

\begin{tabular}{lllll}
\hline Experimental diets & $\alpha$-tocopherol levels $\left(\mathrm{mg} \mathrm{kg}^{-1}\right)$ & $\mathrm{CP}$ & $\mathrm{EE}$ & $\mathrm{GE}\left(\mathrm{kcal} \mathrm{g}^{-1}\right)$ \\
\hline Diet I & 0 & $14.55 \pm 0.78^{\mathrm{a}}$ & $2.84 \pm 0.10^{\mathrm{a}}$ & $2.13 \pm 0.15^{\mathrm{b}}$ \\
Diet II & 100 & $11.35 \pm 0.25^{\mathrm{e}}$ & $1.78 \pm 0.16^{\mathrm{b}}$ & $1.76 \pm 0.04^{\mathrm{ab}}$ \\
Diet III & 200 & $9.02 \pm 0.33^{\mathrm{e}}$ & $2.23 \pm 0.09^{\mathrm{d}}$ & $1.73 \pm 0.08^{\mathrm{ab}}$ \\
Diet IV & 300 & $10.94 \pm 0.03^{\mathrm{f}}$ & $2.30 \pm 0.02^{\mathrm{f}}$ & $1.56 \pm 0.13^{\mathrm{b}}$ \\
Diet V & 400 & $11.49 \pm 0.33^{\mathrm{d}}$ & $2.39 \pm 0.03^{\mathrm{e}}$ & $1.86 \pm 0.01^{\mathrm{b}}$ \\
Diet VI & 500 & $12.47 \pm 0.43^{\mathrm{c}}$ & $2.48 \pm 0.03^{\mathrm{d}}$ & $1.94 \pm 0.01^{\mathrm{ab}}$ \\
Diet VII & 600 & $13.93 \pm 0.06^{\mathrm{b}}$ & $2.65 \pm 0.04^{\mathrm{c}}$ & $2.06 \pm 0.02^{\mathrm{ab}}$ \\
\hline
\end{tabular}

Means within rows having different superscripts are significantly different at $\mathrm{p}<0.05$

Data are means of three replicates

Table 5. Apparent digestibility coefficient (\%) of corn gluten meal based diet with $\alpha$-tocopherol supplementation in $L$. rohita fingerlings

\begin{tabular}{lllll}
\hline Experimental diets & $\alpha$-tocopherol levels $\left(\mathrm{mg} \mathrm{kg}^{-1}\right)$ & $\mathrm{CP}$ & $\mathrm{EE}$ & $\mathrm{GE}$ \\
\hline Diet I & 0 & $55.05 \pm 0.55^{\mathrm{g}}$ & $61.18 \pm 0.20^{\mathrm{d}}$ & $52.37 \pm 0.84^{\mathrm{b}}$ \\
Diet II & 100 & $65.97 \pm 0.77^{\mathrm{c}}$ & $66.19 \pm 0.93^{\mathrm{c}}$ & $60.09 \pm 0.72^{\mathrm{ab}}$ \\
Diet III & 200 & $73.57 \pm 0.34^{\mathrm{b}}$ & $74.48 \pm 0.76^{\mathrm{a}}$ & $63.61 \pm 0.94^{\mathrm{a}}$ \\
Diet IV & 300 & $68.72 \pm 0.81^{\mathrm{a}}$ & $72.67 \pm 0.41^{\mathrm{ab}}$ & $61.43 \pm 0.26^{\mathrm{a}}$ \\
Diet V & 400 & $67.06 \pm 0.33^{\mathrm{d}}$ & $73.72 \pm 0.04^{\mathrm{b}}$ & $59.74 \pm 0.47^{\mathrm{ab}}$ \\
Diet VI & 500 & $63.95 \pm 0.45^{\mathrm{e}}$ & $71.70 \pm 0.82^{\mathrm{b}}$ & $58.00 \pm 0.86^{\mathrm{ab}}$ \\
Diet VII & 600 & $59.69 \pm 0.16^{\mathrm{f}}$ & $70.26 \pm 0.26^{\mathrm{b}}$ & $54.55 \pm 0.35^{\mathrm{ab}}$ \\
\hline
\end{tabular}

Means within rows having different superscripts are significantly different at $\mathrm{p}<0.05$

Data are means of three replicates

Table 6. Antioxidant activity of $\alpha$-tocopherol supplemented corn gluten meal diets in L. rohita fingerlings

\begin{tabular}{llll}
\hline Experimental diets & $\alpha$-tocopherol levels $\left(\mathrm{mg} \mathrm{kg}^{-1}\right)$ & Absorbance & Oxidation (\%) \\
\hline Diet I & 0 & $0.0274 \pm 0.00012$ & $100.00 \pm 0.00$ \\
Diet II & 100 & $0.0258 \pm 0.00010$ & $95.89 \pm 0.35$ \\
Diet III & 200 & $0.0239 \pm 0.00019$ & $78.34 \pm 0.84$ \\
Diet IV & 300 & $0.088 \pm 0.00013$ & $45.28 \pm 0.62$ \\
Diet V & 400 & $0.0072 \pm 0.00022$ & $31.15 \pm 0.34$ \\
Diet VI & 500 & $0.0064 \pm 0.00015$ & $17.23 \pm 0.38$ \\
Diet VII & 600 & $0.0017 \pm 0.00011$ & $7.66 \pm 0.44$ \\
\hline
\end{tabular}

the best because oxidation (\%) was minimum $(7.66 \%)$ as compared to other diets. Decreasing trend of oxidation was observed with increasing level of $\alpha$-tocopherol in all the groups.

\section{Discussion}

Vitamin $\mathrm{E}$ is considered as one of the important vitamins due to its vital role in improving physiological processes of life. For commonly cultured fish species, optimum dietary range of $\alpha$-tocopherol is $6.25-200 \mathrm{mg} \mathrm{kg}^{-1}$ (NRC, 2011). The quantitative dietary $\alpha$-tocopherol requirement of $L$. rohita based on corn gluten meal is $200 \mathrm{mg} \mathrm{kg}^{-1}$, which is relatively lower than that of Piaractus mesopotamicus (Pacu) which is $250 \mathrm{mg} \mathrm{kg}^{-1}$ (Garcia et al., 2007), while relatively higher than that of Cirrhinus mrigala (mrigal) - $99 \mathrm{mg} \mathrm{kg}^{-1}$ (Paul et al., 2004), Rachycentron canadum (Cobia) - 78 or $111 \mathrm{mg} \mathrm{kg}^{-1}$ (Zhou et al., 2013) and Ctenopharyngodon idella (Grass carp) - $100.36 \mathrm{mg} \mathrm{kg}^{-1}$ (Li et al., 2014). The difference in dietary requirement of each species is attributed to rearing conditions, synergistic effect of vitamin $\mathrm{E}$ with other antioxidants present in the diet, fish species, different vitamin E storage capacity of each organ and size and life stage of fish (Lozano et al., 2017).

In the present study, parameters related to growth performance significantly enhanced in $\alpha$-tocopherol supplemented groups when compared with the control group. In terms of $\mathrm{WG}, \mathrm{WG} \%$ and $\mathrm{FCR}$, L. rohita fingerlings fed $200 \mathrm{mg} \mathrm{kg} \mathrm{kg}^{-1}$ of $\alpha$-tocopherol showed improved results. Our results co-relate with Kim et al. (2015) who evidenced that $200 \mathrm{mg} \mathrm{kg}^{-1}$ of vitamin $\mathrm{E}$ to Panaeolus olivaceus enhanced the growth of fish significantly. Muchlisin et al. (2016) reported in their study that $150 \mathrm{mg} \mathrm{kg}^{-1}$ of $\alpha$-tocopherol in feed supplemented to keureling (Tor tambra) is an optimum dosage for better growth. Significant increase in WG, SGR and FCR was observed when Gao et al. (2012) fed red sea bream juveniles at 100 and $200 \mathrm{mg} \mathrm{kg}^{-1}$ vitamin E supplemented 
diet, as compared to the control fish fed without vitamin $\mathrm{E}$ supplemented diets.

Sau et al. (2004) also gave positive results of vitamin E supplementation for 12 weeks in L. rohita in lerms of SGR, WG and FCR. Wang et al. (2019) found growth promoting effects of dietary vitamin $\mathrm{E}$ at 68.75 $\mathrm{mg} \mathrm{kg}{ }^{-1}$ in Nibea albiflora (Yellow drum) juveniles and


Pan et al. (2017) described that vitamin E deficient diet depressed the SGR and $\mathrm{WG} \%$ in C. idella, while optimal vitamin E supplemented diet reversed the negative growth parameters. Supplementation of vitamin E at $480 \mathrm{mg} \mathrm{kg}^{-1}$ in S. maximus (turbot) improved growth performance and provided suitable FCR value (Jia et al., 2017). Improved digestibility of crude protein, total lipids and dry matter of Notemigonus crysoleucas (golden shiner) was observed by Chen et al. (2004) by feeding $98 \mathrm{mg} \mathrm{AA} \mathrm{kg}{ }^{-1} \alpha-\mathrm{T}$ supplemented diets to the fish.

Vitamin $\mathrm{E}$ is a potent antioxidant that protects fish tissues from oxidative damage (Rainis et al., 2007). Function of antioxidant system is to balance dynamically the production and removal of free radicals at an equal rate. In case of high number of free radicals, peroxidation of lipid membranes takes place. Important antioxidant enzymes in the fish body are superoxide dismutase (SOD), glutathione peroxidase (GPx) and catalase (CAT) which have the potential to balance free radicals' concentration in the body (Jia et al., 2017). Linn et al. (2014) treated the red seabream with vitamin E supplemented diets and evidenced that $200 \mathrm{mg} \mathrm{kg}^{-1}$ of $\alpha$-tocopherol reduced lipid peroxidation in fish muscles and improved health status of the fish as well. Sahoo and Mukherjee (2002) explained that the use of vitamin $\mathrm{E}\left(1000 \mathrm{mg} \mathrm{kg}^{-1}\right)$ in L. rohita which is even greater than recommended level leads to improved immunity and enhances protection of cellular membranes from oxidative damage. Tocher et al. (2002) found decreased levels of $\alpha$-tocopherol in tissues of fish fed with low dietary $\alpha$-tocopherol level and generally decreased activities of the liver antioxidant enzymes and higher levels of lipid peroxides in juvenile turbot (S. maximus L.), halibut (Hippoglossus hippoglossus L.) and seabream (Sparus aurata L.). Vitamin E at the level of $150 \mathrm{mg} \mathrm{kg}^{-1}$ in the feed led to an increase in blood antioxidant activity in Coturnix coturnix japonica (Shah et al., 2016).

Muchlisin et al. (2016) concluded that the optimum dose for keureling (T. tambra) was $150 \mathrm{mg} \mathrm{kg}^{-1}$ of vitamin $\mathrm{E}$ in feed. Addition of more than $100 \mathrm{mg} \mathrm{kg}^{-1}$ vitamin $\mathrm{E}$ could stop tissues from lipid oxidation as well as better growth and health of juvenile red seabream (Gao et al., 2012). Higher SOD activity at $36.2 \mathrm{mg} \mathrm{kg}^{-1}$ of vitamin $E$ in N. albiflora was noted down by Wang et al. (2019); in addition to it, low level of serum malondialdehyde (MAD) was also present at the same level and hence resulted in improved antioxidant activity. Huang and Huang (2004) reported that vitamin E deficient diet in hybrid tilapia (Oreochromis niloticus $\times O$. aureus) resulted in elevated levels of MAD in muscular and liver tissues, hence oxidatively damaged the fish. Pan et al. (2017) stated vitamin E deficiency related reduced antioxidant activity in grass carp because radical scavenging ability in head, kidney and spleen of fish was depressed and MAD level started to elevate. Hong et al. (2004) explained that $\alpha$-tocopherol as an antioxidant inhibits superoxide radical accumulation in the brain of streptozotocininduced diabetic rats. Reduction of antioxidant enzyme activity is attributed to decrease in mRNA levels of fish immune system (Xu et al., 2016). Jia et al. (2017) also noted renewed antioxidant enzyme activity at $480 \mathrm{mg} \mathrm{kg}^{-1}$ of vitamin $\mathrm{E}$ in turbot and so lipid peroxidation was prevented.

A contradictory result was found by Chen et al. (2004) regarding WG, FCR and feed intake (FI) in $N$. crysoleucas fed on vitamin $\mathrm{C}$ and vitamin $\mathrm{E}$ supplemented diets even after 14 weeks. This is because vitamin $\mathrm{C}$ leads to the sparing effect on vitamin $\mathrm{E}$, in which oxidised vitamin $\mathrm{E}$ can be reduced again by ascorbate (Tappel, 1972). It affects growth performance, fillet composition or immunological parameters and has been noted in some fish species (Yildirim-Aksoy et al., 2008; Hamre, 2011; Betancor et al., 2012). Duration of feeding trial also exerts impact on vitamin E depletion or deposition. Similarly, Gao et al. (2013) and Sahoo and Mukherjee (2002) noticed insignificant change on growth performance of Apostichopus japonicus and L. rohita, respectively after using vitamin $\mathrm{E}$ supplemented diets. They used 2-5 folds higher vitamin level than that required for fishes. This difference may be due to excessive levels of vitamins in the diet. Similarly, SGR (1.4 to $1.5 \%)$, FI (1.9 to $2.1 \mathrm{~g} \mathrm{fish}^{-1}$ day $\left.^{-1}\right)$ and FCR (0.73 to 0.95$)$ was detected in $A$. regius when fed on vitamin E supplemented diets (Lozano et al., 2017). This divergence can be explained on the basis of different feeding trial period (72 days) and high concentration of vitamin $\mathrm{C}\left(5000 \mathrm{mg} \mathrm{kg}^{-1}\right)$ in the diet.

The results of the present study revealed that $\alpha$-tocopherol supplementation in corn gluten meal based diet has significant effect on growth performance, nutrient digestibility and antioxidant activity of $L$. rohita fingerlings at dietary level of $200 \mathrm{mg} \mathrm{kg}^{-1}$. Such inclusion level of $\alpha$-tocopherol resulted in improved antioxidant activity by lowering oxidation of lipids in L. rohita. Therefore, corn gluten meal along with supplementation of $\alpha$-tocopherol proved to be a cheap and highly productive fish feed which is expected to produce nutritionally healthy fish. 


\section{References}

Allan, G. L. and Rowland, S. J. 1992. Development of an experimental diet for silver perch (Bidyanus bidyanus). Aust. Aquac., 6: 39-40.

AOAC 1995. Official methods of analysis, $15^{\text {th }}$ edn. Association of Official Analytical Chemists, Washington D. C., USA, $1094 \mathrm{pp}$.

Bai, N., Gu, M., Liu, M., Jia, Q., Pan, S. and Zhang, Z. 2019. Corn gluten meal induces enteritis and decreases intestinal immunity and antioxidant capacity in turbot (Scophthalmus maximus) at high supplementation levels. PLoS One, 14(3): e0213867. https://doi.org/10.1371/journal.pone.0213867.

Bender, D. A. 2003. Nutritional biochemistry of the vitamins. Cambridge University Press, Cambridge, UK.

Betancor, M. B., Caballero, M. J., Terova, G., Cora, S., Saleh, R., Benitez-Santana, T., Bell, J. G., Hernandez-Cruz, C. M. and Izquierdo, M. 2012. Vitamin C enhances vitamin E status and reduces oxidative stress indicators in seabass larvae fed high DHA microdiets. Lipids, 47(12): 1193-1207. https://doi.org/10.1007/s11745-012-3730-x.

Cha, J. Y., Flores, R. A. and Park, H. 2000. Reduction of carotenoids in corn gluten meal with soy flour. Trans. ASAE, 43(5): 1169-1174. doi: 10.13031/2013.3009.

Chen, R., Lochmann, R., Goodwin, A., Praveen, K., Dabrowski, K. and Lee, K. J. 2004. Effects of dietary vitamins $\mathrm{C}$ and $\mathrm{E}$ on alternative complement activity, hematology, tissue composition, vitamin concentrations and response to heat stress in juvenile golden shiner (Notemigonus crysoleucas). Aquaculture, 242(1-4): 553-569. https://doi.org/10.1016/j.aquaculture.2004.09.012.

Divakaran, S., Leonard, G. O. and Lan, P. F. 2002. Note on the methods for determination of chromic oxide in shrimp feeds. J. Agric. Food Chem., 50(3): 464-467. https://doi. org/10.1021/jf011112s.

FAO 2012. The state of world fisheries and aquaculture. Food and Agriculture Organisation of the United Nations, Rome, Italy, $230 \mathrm{pp}$.

Gao, J., Koshio, S., Ishikawa, M., Yokoyama, S., Mamauag, R. E.P. and Han, Y. 2012. Effects of dietary oxidized fish oil with vitamin $\mathrm{E}$ supplementation on growth performance and reduction of lipid peroxidation in tissues and blood of red seabream Pagrus major. Aquaculture, 356: 73-79. https:// doi.org/10.1016/j.aquaculture.2012. 05.034.

Gao, J., Koshio, S., Ishikawa, M., Yokoyama, S., Nose, D. and Ren, T. 2013. Interactive effects of vitamin C and E supplementation on growth, fatty acid composition, and lipid peroxidation of sea cucumber, Apostichopus japonicus, fed with dietary oxidized fish oil. J. World Aquac. Soc., 44(4): 536-546. https://doi.org/10.1111/ jwas. 12048 .

Garcia, F., Pilarski, F., Onaka, E. M., Moraes, F. R. and Martins, M. L. 2007. Hematology of Piaractus mesopotamicus fed diets supplemented with vitamins
$\mathrm{C}$ and E, challenged by Aeromonas hydrophila. Aquaculture, 271(1-4): 39-46. https://doi.org/10.1016/j. aquaculture.2007.06.021.

Glencross, B. 2016. Understanding the nutritional and biological constraints of ingredients to optimize their application in aquaculture feeds. In: Sergio Nates (Ed.), Aquafeed formulation, $1^{\text {st }}$ edn. Academic Press, Cambridge, UK, p. 33-73.

Goswami, R., Shrivastav, K., Sharma, A. K., Tocher, J. G. and Chakrabarti, R. 2020. Growth and digestive enzyme activities of rohu Labeo rohita fed diets containing macrophytes and almond oil-cake. Anim. Feed Sci. Tech., 263. https://doi.org/10.1016/j.anifeedsci.2020.114456.

Hamre, K. 2011. Metabolism, interaction, requirements and functions of vitamin E in fish diet. Aquac. Nutr., 17(1): 98-115. https://doi.org/10.1111/j.1365-2095.2010.00806.x.

Hong, J. H., Kim, M. J., Park, M. R., Kwag, O. G. Lee, I. S., Byun, B., Lee, S. C., Lee, K. B. and Rhee, S. J. 2004. Effects of vitamin $\mathrm{E}$ on oxidative stress and membrane fluidity in brain of streptozotocin-induced diabetic rats. Clin. Chim. Acta., 340: 107-115. https://doi.org/10.1016/j.cccn. 2003.10.003.

Huang, C. H. and Huang, S. L. 2004. Effect of dietary vitamin E on growth, tissue lipid peroxidation and liver glutathione level of juvenile hybrid tilapia, Oreochromis niloticus $\times O$. aureus, fed oxidized oil. Aquaculture, 237(1-4): 381-389. https://doi.org/10.1016/j.aquaculture.2004.04.002.

Hussain, A. I., Anwar, F., Iqbal, T. and Bhatti, I. A. 2011 Antioxidant attributes of four Lamiaceae essential oils. Pak. J. Bot., 43(2): 1315-1321.

Jia, Y., Jing, Q., Niu, H. and Huang, B. 2017. Ameliorative effect of vitamin $\mathrm{E}$ on hepatic oxidative stress and hypoimmunity induced by high-fat diet in turbot (Scophthalmus maximus). Fish Shellfish Immunol., 67: 634-642. https:// doi.org/10.1016/j.fsi.2017. 06.056.

Kim, S. M., Jun, L. J., Park, M., Jeong, H. D. and Jeong, J. B. 2015. Characterisation of the myxoporean parasite isolated from emaciated olive flounder Paralichthys olivaceus on Jeju Island. Korean J. Fish. Aquat. Sci., 48(3): 337-345. https://doi.org/10.5657/ KFAS.2015.0337.

Lee, S. K., Kim, L. C. Y. and Song, Y. H. 2003. Effects of dietary vitamin E supplementation on color stability, lipid oxidation and reducing ability of Hanwoo (Korean cattle) beef during retail display. Asian Austr. J. Anim. Sci., 16(10): 1529-1534. https://doi. org/10.5713/ajas.2003.1529.

Li, J., Liang, X. F., Tan, Q., Yuan, X., Liu, L., Zhou, Y. and Li, B. 2014. Effects of vitamin $E$ on growth performance and antioxidant status in juvenile grass carp Ctenopharyngodon idella. Aquacuture, 430: 21-27. https://doi.org/10.1016/j. aquaculture.2014.03.019.

Linn, S. M., Ishikawa, M., Koshio, S. and Yokoyama, S. 2014. Effect of dietary vitamin E supplementation on growth performance and oxidative condition of red sea bream 
Pagrus major. Aquat. Sci., 62(4): 329-339. https://doi. org/10.11233/ aquaculturesci.62.329.

Liu, B., Xu, P., Xie, J., Ge, X., Xia, S., Song, C., Zhou, Q., Miao, L., Ren, M., Pan, L. and Chen, R. 2014. Effects of emodin and vitamin $\mathrm{E}$ on the growth and crowding stress of Wuchang bream (Megalobrama amblycephala). Fish Shellfish Immunol., 40(2): 595-602. doi: 10.1016/j.fsi. 2014.08.009.

Lovell, R. T. 1989. Nutrition and feeding of fish. Van NostrandReinhold, New York, USA, 260 pp.

Lozano, A. R., Borges, P., Robaina, L., Betancor, M., HernandezCruz, C. M., García, J. R. Caballero, M. J., Vergara, J. M. and Izquierdo, M. S. 2017. Effect of different dietary vitamin $\mathrm{E}$ levels on growth, fish composition, fillet quality and liver histology of meagre (Argyrosomus regius). Aquaculture, 468: 175-183. http://hdl.handle.net/ $1893 / 24589$.

Luo, Y., Ai, Q., Mai, K., Zhang, W., Xu, W., Zhang, Y. and Liufu, Z. 2013. Effects of dietary corn gluten meal on growth performance and protein metabolism in relation to IGF-I and TOR gene expression of juvenile cobia (Rachycentron canadum). J. Ocean U. China, 12(3): 418-426. https://doi.org/10.1007/s11802-013-2021-3.

Men, K., Ai, Q., Mai, K., Xu, W., Zhang, Y. and Zhou, H. 2014. Effects of dietary corn gluten meal on growth, digestion and protein metabolism in relation to IGF-I gene expression of Japanese seabass, Lateolabrax japonicus. Aquaculture, 428: 303-309. doi: 10.1016/j. aquaculture.2014.03.028.

Mohapatra, S., Chakraborty, T., Prusty, A., Das, P., Paniprasad, K. and Mohanta, K. 2012. Use of different microbial probiotics in the diet of rohu, Labeo rohita fingerlings: Effects on growth, nutrient digestibility and retention, digestive enzyme activities and intestinal microflora. Aquac. Nutr., 18(1): 1-11. https://doi.org/10. 1111/j.1365-2095.2011.00866.x.

Molina-Poveda, C., Lucas, M. and Jover, M. 2015. Utilisation of corn gluten meal as a protein source in the diet of white shrimp Litopenaeus vannamei. Aquac. Nutr., 21(6): 824-834. https://doi.org/10.1111/anu.12209.

Muchlisin, Z. A., Arisa, A. A., Muhammadar, A. A., Fadli, N., Arisa, I. I. and Siti-Azizah, M. N. 2016. Growth performance and feed utilization of keureling (Tor tambra) fingerlings fed a formulated diet with different doses of vitamin E (alpha-tocopherol). Arch. Polish Fish., 24(1): 47-52. doi: 10.1515/aopf-2016-0005.

NRC 1993. Nutrient requirements of fish. National Academic Press, Washington DC, USA, 114 pp.

NRC 2011. Nutrient requirements of fish and shrimp. National Academies Press, Washington DC, USA.

Pan, J. H., Feng, L., Jiang, W. D., Wu, P., Kuang, S. Y., Tang, L., Zhang, Y. A., Zhou, X. Q. and Liu, Y. 2017. Vitamin E deficiency depressed fish growth, disease resistance and the immunity and structural integrity of immune organs in grass carp (Ctenopharyngodon idella): Referring to NF$\kappa \mathrm{B}$, TOR and Nrf2 signaling. Fish Shellfish Immunol., 60: 219-236. doi: 10.1016/j.fsi.2016.11.044.

Paul, B. N., Sarkar, S. and Mohanty, S. N. 2004. Dietary vitamin E requirement of mrigal, Cirrhinus mrigala fry. Aquaculture, 242(1-4): 529-536. doi: 10.1016/j. aquaculture.2004.08.037.

Peng, S., Chen, L., Qin, J. G., Hou, J., Yu, N., Long, Z., Li, E. and Ye, J. 2009. Effects of dietary vitamin E supplementation on growth performance, lipid peroxidation and tissue fatty acid composition of black sea bream (Acanthopagrus schlegeli) fed oxidized fish oil. Aquac. Nutr., 15(3): 329-337. https://doi.org/10.1111/j.1365-2095.2009. 00657.x.

Rainis, S., Gasco, L., Ballestrazzi, R. and Zoccarato, I. 2007. Effects of vitamin $E$ and phosphatidylcholine on qualitative and quantitative parameters of rainbow trout (Oncorhynchus mykiss) milt. Ital. J. Anim. Sci., 6(4): 339-350. doi: 10.4081/ijas.2007.339.

Sahoo, P. K. and Mukherjee, S. C. 2002. Influence of high dietary $\alpha$-tocopherol intakes on specific immune response, nonspecific resistance factors and disease resistance of healthy and aflatoxin B1-induced immunocompromised Indian major carp, Labeo rohita (Hamilton). Aquac. Nutr., 8(3): 159-167. https://doi.org/10.1046/j.1365-2095. 2002.00189.x

Salinthone, S., Kerns, A. R., Tsang, V. and Carr, D. W. 2013. atocopherol (vitamin E) stimulates cyclic AMP production in human peripheral mononuclear cells and alters immune function. Mol. Immunol., 53(3): 173178. doi: 10.1016/j. molimm. 2012.08.005.

Sau, S. K., Paul, B. N., Mohanta, K. N. and Mohanty, S. N. 2004. Dietary vitamin E requirement, fish performance and carcass composition of rohu (Labeo rohita) fry. Aquaculture, 240(1-4): 359-368. doi: 10.1016/j. aquaculture.2004.02.008

Shah, A. A., Khan, M. S., Khan, S., Ahmad, N., Alhidary, I. A., Khan, R. U. and Shao, T. 2016. Effect of different levels of alpha tocopherol on performance traits, serum antioxidant enzymes and trace elements in Japanese quail (Coturnix coturnix japonica) under low ambient temperature. Rev. Bras. Zoot., 45(10): 622-626. https://doi.org/10.1590/ S1806-92902016001000007.

Snedecor, G. W. and Cochran, W. G. 1990. Statistical methods, $8^{\text {th }}$ edn. Iowa State University Press, Iowa, USA, $503 \mathrm{pp}$.

Steel, R. G. D., Torrie, J. H. and Dickey, D. A. 1996. Principles and procedures of statistics, $3^{\text {rd }}$ edn. McGraw Hill International Book Co. Inc., New York, USA.

Tappel, A. L. 1972. Vitamin E and free radical peroxidation of lipids. Annals of the New York. Academy of Sciences, 203(1): 12-28. 
Teves, J. F. C. and Ragaza, J. A. 2016. The quest for indigenous aquafeed ingredients: A review. Rev. Aquac., 8(2): 154-171. https://doi.org/10.1111/raq.12089.

Tocher, D. R., Mourente, G., Van der Eecken, A., Evjemo, J. O., Diaz, E., Bell, J. G., Geurden, I., Lavens, P. and Olsen, Y. 2002. Effects of dietary vitamin $\mathrm{E}$ on antioxidant defence mechanisms of juvenile turbot (Scophthalmus maximus L.), halibut (Hippoglossus hippoglossus L.) and sea bream (Sparus aurata L.). Aquac. Nutr., 8(3): 195-207. https:// doi.org/10.1046/j.1365-2095.2002.00205.x.

Wang, L. G., Li, E. C., Qin, J. G., Du, Z. Y., Yu, N., Kong, Y. Q., Feng, D. X. and Chen, L. Q. 2015. Effect of oxidized fish oil and $\alpha$-tocopherol on growth, antioxidation status, serum immune enzyme activity and resistance to Aeromonas hydrophila challenge of Chinese mitten crab Eriocheir sinensis. Aquac. Nutr., 21(4): 414-424. https://doi.org/ 10.1111/anu.12171

Wang, L., Ma, B., Chen, D., Lou, B., Zhan, W., Chen, R., Tan, P., Xu, D., Liu, F. and Xie, Q. 2019. Effect of dietary level of vitamin $\mathrm{E}$ on growth performance, antioxidant ability and resistance to Vibrio alginolyticus challenge in yellow drum Nibea albiflora. Aquaculture, 507: 119-125. doi: 10.1111/ jwas. 12636.

Wang, Y. H., Yuan, Y., Yang, X. Q., Wang, J. M., Guo, J. and Lin, Y. 2016. Comparison of the colloidal stability, bioaccessibility and antioxidant activity of corn protein hydrolysate and sodium caseinate stabilized curcumin nanoparticles. J. Food Sci. Tech., 53(7): 2923-2932. doi: 10.1007/s13197-016-2257-1.
Xu, H. J., Jiang, W. D., Feng, L., Liu, Y., Wu, P., Jiang, J., Kuang, S. Y., Tang, W. N., Zhang, Y. A. and Zhou, X. Q. 2016. Dietary vitamin $C$ deficiency depresses the growth, head kidney and spleen immunity and structural integrity by regulating NF- $\mathrm{KB}$, TOR, Nrf2, apoptosis and MLCK signaling in young grass carp (Ctenopharyngodon idella). Fish Shellfish Immunol., 52: 111-138. doi: 10.1016 jj.fsi.2016.02.033.

Yigit, M., Bulut, M., Ergün, S., Güroy, D., Karga, M., Kesbic, O. S., Yilmaz, S., Acar, U. and Güroy, B. 2012. Utilization of corn gluten meal as a protein source in diets for gilthead sea bream (Sparus aurata L.) juveniles. J. Fish. Sci., 6(1): 63-73.

Yildirim-Aksoy, M., Lim, C., Li, M. H. and Klesius, P. H. 2008. Interaction between dietary levels of vitamins $\mathrm{C}$ and $\mathrm{E}$ on growth and immune responses in channel catfish, Ictalurus punctatus (Rafinesque). Aquac. Res., 39(11): 1198-1209. https://doi.org/10.1111/j.1365-2109.2008.01984.x.

Zhang, C. X., Huang, F., Li, J., Wang, L., Song, K. and Mai, K. S. 2016. Interactive effects of dietary magnesium and vitamin $\mathrm{E}$ on growth performance, body composition, blood parameters and antioxidant status in Japanese seabass (Lateolabrax japonicus) fed oxidized oil. Aquac. Nutr., 22: 708-722. https://doi.org/10.1111/anu.12393.

Zhou, Q. C., Wang, L. G., Wang, H. L., Wang, T., Elmada, C. Z. and Xie, F. J. 2013. Dietary vitamin E could improve growth performance, lipid peroxidation and non-specific immune responses for juvenile cobia (Rachycentron canadum). Aquac. Nutr., 19(3): 421-429. https://doi. org/10.1111/j.1365-2095.2012.00977.x. 